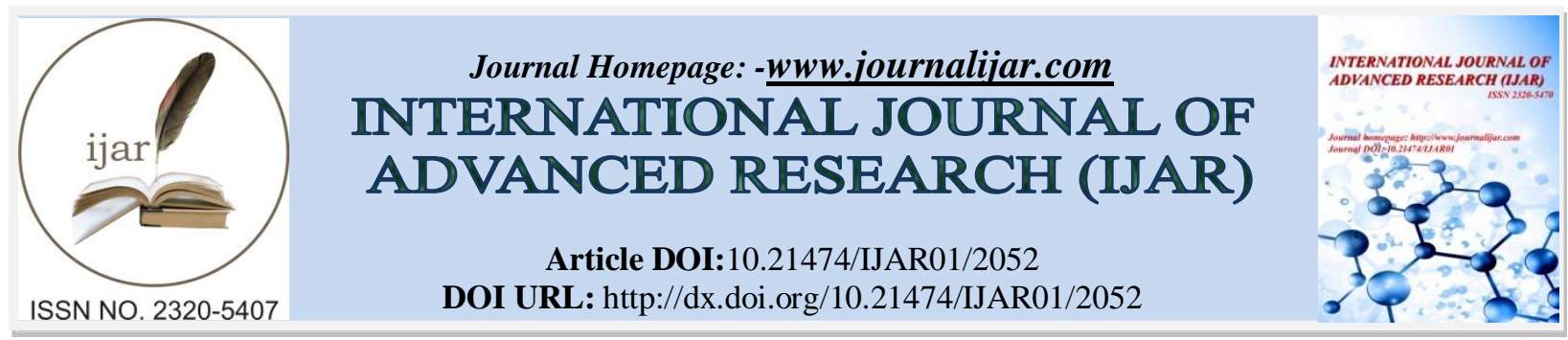

RESEARCH ARTICLE

\title{
EFFECT OF AQUEOUS EXTRACT OF BITTER LEAF (VERNONIA AMYGDALINA) ON PHENYL- HYDRAZINE INDUCED KIDNEY DAMAGE IN ALBINO RAT.
}

\section{L. Hamman ${ }^{1 *}$, D. S. Amaza ${ }^{2}$, J. V. Zirahei ${ }^{1}$ A. D. T. Goji ${ }^{3}$ H. Mari ${ }^{4}$ and F. Amali ${ }^{1}$}

1. Department of Human Anatomy, College of Medical Sciences, University of Maiduguri, Borno State, Nigeria.

2. Department of Anatomy, Faculty of Medicine, Kaduna State University, Kaduna State, Nigeria

3. Department of Human Physiology, Faculty of Medicine, Kaduna State University, Kaduna State, Nigeria.

4. Department of Biological Sciences, Faculty Science, University of Maiduguri, Borno State, Nigeria.

\section{Manuscript Info}

Manuscript History

Received: 20 September 2016

Final Accepted: 22 October 2016

Published: November 2016

Key words:-

VernoniaAmygdalina, Phenyl hydrazine,

Kidney Albino rats, Bitter leaf.

\section{Abstract}

Introduction:-Vernoniaamygdalina (Asteraceae) known as bitter leaf is commonly consumed in many parts of Africa as leafy vegetable and is used in ethno-medicine to treat various illnesses. This study was undertaken to determine the effects of VernoniaAmygdalinaon Phenyl hydrazine induced kidney damage in rats.

Methodology:- Thirty (30) Albino rats were randomly divided into five groups of six rats each $(n=6)$. Group 1 was normal control and the rats were fed with standard rat pellets diets and water. Groups 2-5 were the experimental group and the rats were treated with equal dose of phenylhydrazine. Group 2 consist of the phenylhydrazine induced kidney damage; the rats were treated with phenyl hydrazine only. Group 3 was administered $500 \mathrm{mg} / \mathrm{kg}$ of the extract simultaneously with phenylhydrazine. Groups 2-3 were sacrificed under chloroform vapour at the fourth day in other to ensure that the level of phenyl hydrazine is enough to induced renal damage. Group 4 was posttreated with $400 \mathrm{mg} / \mathrm{kg}$ of the extract for 14 days. Group 5 was posttreated with $300 \mathrm{mg} / \mathrm{kg}$ of the extract for 28 days. Groups 4-5 were then euthanized under chloroform vapour and were sacrificed immediately after the respective final day of administration. The kidney was surgically removed, immediately blotted using filter paper to remove traces of blood, weighed with an analytical balance then fixed in $10 \%$ formal saline preparatory to histological processing.

Results:-The experimental animals treated with phenylhydrazine only were observed to produce body weakness, loss of appetite, decline body weight, respiratory distress.

Conclusion:- The results suggest that Vernoniaamygdalina (bitter leaf) have great level of renal recovery from phenylhydrazine induced kidney damage. It has nephro-protective effects; it is therefore safe to consume so as to enhance renal functioning. Further research should be carried out in humans because renal disease is a problem now globally.

Copy Right, IJAR, 2016,. All rights reserved.
Corresponding Author:-L. L. Hamman.

Address:-Department of Human Anatomy, College of Medical Sciences, University of Maiduguri, Borno State, Nigeria. 


\section{Introduction:-}

VernoniaAmygdalina (VA) is a shrub of $2-5 \mathrm{~m}$ with petiolate leaf of about $6 \mathrm{~mm}$ in diameter and elliptic in shape. The leaves of this plant are used in Nigeria as green vegetable or as a spice in soup, especially in the popular bitter leaf soup. The leaves have been found to have relevance in traditional folk medicine as anti-helmint, a laxative herb and and ant-malaria as they are known as quinine substitute (Huffman and Seifu, 1989). The leaves are eaten in many parts of Africa. It is prepared like spinach and used in soups and stews while "chew stick" from the root and twig are enjoyed as an appetizer (Hutchioson et al, 1963).

It is known as 'Ewuro' in Yoruba, 'Etidot' in Ibibio, 'Onugbu' in Igbo and 'Chusa-diki' in Hausa tribes in Nigeria (Egedigwe, 2010). VA grows under a range of ecological zones in Africa and produces large mass of forage and is drought tolerant; it is found in homes in villages as fence post and pot-herb (Bonsiet al.,1995). The leaves are used as soup condiment and washed before eating to get rid of the bitter taste. They are used as vegetable in meals to stimulate the digestive system, and as a treatment for fever. A wide array of phytochemicals has been shown to be present in VA. The presence of oxalates, phytates and tannins have been reported (Udensi,et al., 2002; Ejohet al., 2007; Eleyinmiet al., 2008), as well as flavonoids (Igileet al., 1994). VA extracts have been shown to exhibit profound ethnomedical and pharmacological properties viz, anti-diabetic, antimalarial, antihelminthic and antibiotic properties (Farombi, 2003).

VernoniaAmygdalina when incorporated in the diet may prevent or delay the onset of breast cancer. According to this research, discovery of water soluble anti-cancer agent (Edotides) from VernoniaAmygdalina inhibit DNA synthesis in a breast cancer cell line (Revligie, 2005).

The leaves and bark in Ethiopia are used as local medicine to ease menstruation pain, as purgative and against urinary inflammation (Fischti, 2006). A leaf decoction is taken as laxative. A purgative enema is made as an expectorant. The leaves are rubbed gently on the skin for itch, parasitic infections, and ringworm, among others. During the puerperum mother may take a decoction of the leave to enhance milk production so as to act as prophylactic against worms in the baby (Muanya, 2005).

The crude chloroform extract of the leaves of bitter leave has a hypoglycaemic activity in both normaglycaemic and alloxan induced hyperglycaemic rates. This research lends supports to the claim that VernoniaAmygdalina may have an antidiabetic effects in diabetics mellitus (Gyanet al, 2005) using agar well and disc diffusion assays, aqueous extract of bitter leaf was found to produce growth inhibiting zones of 15.6 to $16.1 \mathrm{~mm}$ for Escherica coli, 15.5 to 16.0 $\mathrm{mm}$ for salmonella typhi, $10.3-15.6 \mathrm{~mm}$ for shiguaspp, $12.1-12.3 \mathrm{~mm}$ for MSSA and MRSA, $15.8-16.7 \mathrm{~mm}$ for Bacillus spp and $11.9-12.3 \mathrm{~mm}$ for streptococcus spp. These results in demonstration of antibacterial activity of VernoniaAmygdalina and further suggest it possible exploitation as a sources natural product (Muanya, 2005).

An investigation on the chemical and nutrients composition four botanical with fungi toxic properties, show that VernoniaAmygdalina contain large quantities of thiamine, pyridoxine, ascorbic acid, gylcine, cysteine and casein lydrosylate, more than other botanicals (Alabiet al,. 2005).

The medicinal use of bitter leaf can be extended to the treatment of skin infection, wound healing (Akpukuet al,. 1999).

\section{Materials and Methods:-}

\section{Collection and preparation of plant extract:-}

Four hundred grammes (400g) of VernoniaAmygdalina (VA) leaves were obtained from a family garden, in Maiduguri district, Borno State. The leafs were sorted and washed to remove debris without squeezing and then dried at room temperature for six days. The dry leaves were crushed to powder form. The powder was collected in a clean cellophane bag and then taken to Chemistry Department of University of Maiduguri where extraction was done using soxhlet extractor method by (Mittel et al, 1981). The sample weighed 52g; it was dissolved in 100mls of distilled water for two hours. The mixture was poured into an extractor and heated for eight (8) hours. The mixture was then evaporated and collected through a condenser. The aqueous extract was poured into a tray and put in the oven set at 60 degree centigrade $\left(0^{c}\right)$ over night. Ten grammes $(10 \mathrm{~g})$ of the dried sample was weighed and dissolved in 50mls of distilled water, the derived mixture was shaken continuously and air- tight for complete dissolution. 


\section{Experimental animal:-}

Thirty (30) male albino rats weighing 120-180g were used for the work. The animals were obtained from the animal house of the Department of Pharmacology, University of Jos and allowed to acclimatize in the animal house of the Department of Human Anatomy, College of Medical Sciences, University of Maiduguri, Borno State for about 2 weeks prior to experimentation. They were kept in properly ventilated cages, where bedding was replaced every two days, at a room temperature of about $27^{\circ} \mathrm{C}$ and 12 hour light/dark cycle. The animals were fed with growers' marsh and water obtained from tap ad libitum.

\section{Experimental design:-}

The dosages of plant extracts used were according to the methods of Ebong et al., (2006).

Thirty (30) Albino rats were randomly divided into five groups of six rats each (n=6). Group 1 was normal control and the rats were fed with standard rat pellets diets and water. Groups 2-5 were the experimental group and the rats were treated with equal dose of phenylhydrazine. Group 2 consist of the phenylhydrazine induced kidney damage; the rats were treated with phenylhydrazine only. Group 3 was administered $500 \mathrm{mg} / \mathrm{kg}$ of the extract simultaneously with phenylhydrazine. The groups 2-3 were sacrificed under chloroform vapour at the fourth day in other to ensure that the level of phenyl hydrazine is enough to induced renal damage. Group 4 was post-treated with $400 \mathrm{mg} / \mathrm{kg}$ of the extract for 14days. Group 5 was post-treated with $300 \mathrm{mg} / \mathrm{kg}$ of the extract for 28 days. Groups $4-5$ were then euthanized under chloroform vapour and were sacrificed immediately after the respective final day of administration. The kidney was surgically removed, immediately blotted using filter paper to remove traces of blood, weighed with an analytical balance then fixed in $10 \%$ formal saline preparatory to histological processing.

\section{Induction of kidney damage:-}

Phenylhydrazine $(750 \mathrm{mg} / \mathrm{kg}$ ) was injected into the rats, followed by $300 \mathrm{mg} / \mathrm{kg}$ of Phenylhydrazine on alternate days, three times to induce morphological changes in the Kidney (Harris et al,. 1975).

\section{Histological analysis:-}

All kidneys obtained were procured using the routine histological laboratory technique. The fixed kidney tissues were sectioned (5-micron thickness) and sections firstly stained with basic dyes, of Heamatoxylin and Eosin (H\&E) according to Conn (Conn, 1946) procedure. A comparative microscopic examination was done using microscope to see if Vernoniaamygdalina was effective to restore the normal histo-architecture of the damaged kidney due to phenylhydrazine administration.

\section{Statistical analysis:-}

Numeric data obtained from the study were expressed as the mean value \pm standard error of mean (SEM). Statistical analysis was done using one way analysis of variance (Anova) and means compared using 1-tail and significance point. Differences among means of control and treated group were determined using SPSS version 16. A probability level of less than 5\% $(\mathrm{P}<0.05)$ was considered significant.3.

\section{Results:-}

\section{Gross anatomical observation:-}

The general behavior of the experimental animals was observed; Loss of hairs in the caudal regions of the phenylhydrazine treated animals, swelling of the limbs, decreased appetite among treated animals and slight increase in weight of the control groups.

Table 1:- Effect of aqueous extract of Vernoniaamygdalina on the mean body weight of Wister Rat.

\begin{tabular}{|l|l|l|l|l|}
\hline Groups & $\begin{array}{l}\text { Dosage }(\mathbf{m g} / \mathbf{k g}) \\
\text { Extract }\end{array}$ & Initial Body Wt $(\mathbf{g})$ & Final Body Wt $(\mathbf{g})$ & Body Difference (g) \\
\hline 1 & - & 124.35 & 182.50 & $120.42 \pm 8.16^{*}$ \\
\hline 2 & - & 194.75 & 183.75 & $194.90 \pm 3.51$ \\
\hline 3 & 500 & 150.20 & 163.25 & $186.0 \pm 10.15^{*}$ \\
\hline 4 & 400 & 173.80 & 170.95 & $180.72 \pm 6.44^{*}$ \\
\hline 5 & 300 & 133.80 & 139.25 & $133.58 \pm 6.95^{*}$ \\
\hline
\end{tabular}




\section{Histological observation:-}

The section of the kidneys procured from treated and control animals were observed under the light microscope. Micrographs obtained from the prominent features seen are presented in their respective plates accordingly. The kidney section obtained from normal control group 1, showed normal kidney structure characterized by presence of renal corpuscles; the glomerulus G, encapsulated by the narrow Bowman's space (arrow); renal tubule (T); interlobular vein $(\mathrm{V})$ as shown in Plate 1.

Kidney section obtained from the phenylhydrazine control group treated with $750 \mathrm{mg} / \mathrm{kg}$; and a maintenance dose of $350 \mathrm{mg} / \mathrm{kg}$ at alternate days, showed histological changes which include degeneration of the glomerulus, distention of bowman's space, cortical haemorrhage $(\mathrm{H})$, focal diffuse tubular degeneration and lymphocytic infiltration (arrow) as shown in Plate 2.

Kidney section obtained from group three treated simultaneously with $500 \mathrm{mg} / \mathrm{kg}$ of bitter leaf aqueous extract with phenylhydrazine showed histological changes; cortical degeneration; focal glomerular degeneration; peri-vascular edema (arrow 2) and lymphocytic infiltration as shown in Plate 3.

Kidney section obtained from group four treated with $400 \mathrm{mg} / \mathrm{kg}$ of the extract for fourteen days showed moderately recovered renal corpuscle but with mild distention of Bowman's space as shown in Plate 4.

Kidney section obtained from group five post- treated with $300 \mathrm{mg} / \mathrm{kg}$ of extract for 28 days showed kidney section with moderate renal cortex and renal corpuscles and moderately distended Bowman's space as in Plate.5.

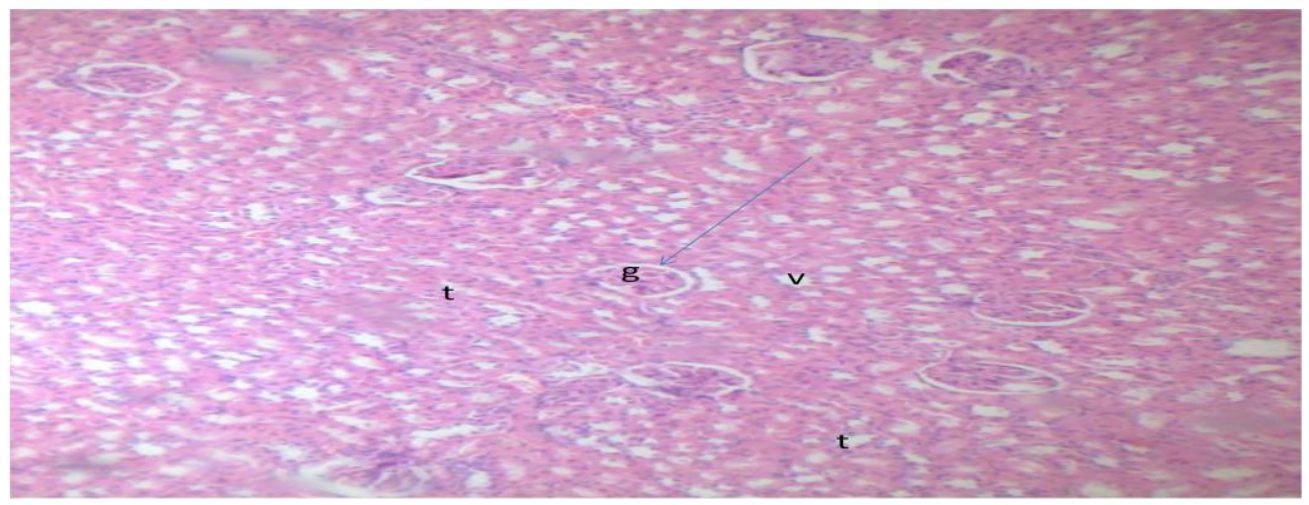

Fig. 1 Photomicrograph of normal rat kidney showing renal corpuscles; Glomerulus G, and renal tubule T,interlobular vein $V, H \& E \times 200$ 


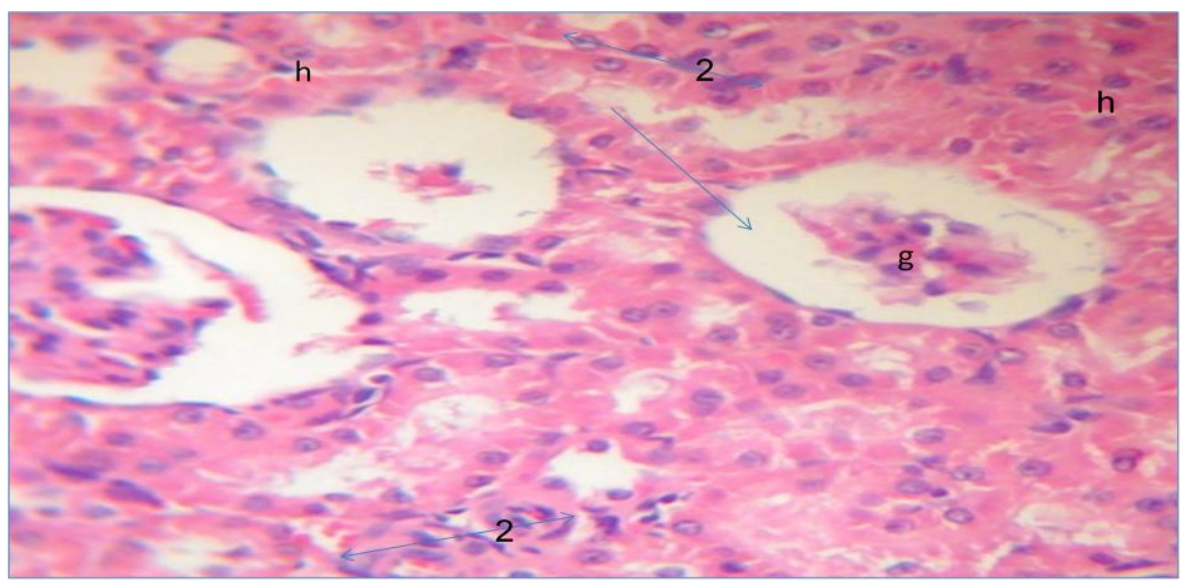

plate 2:photomicrograph of rat; experimental control showing;glomerular degeneration g, distention of bowman's space (arrow),tubular degeneration t, lymphocytic infiltration of renal cortex(arrow2) and cortical haemorrhage h. H\&Ex400

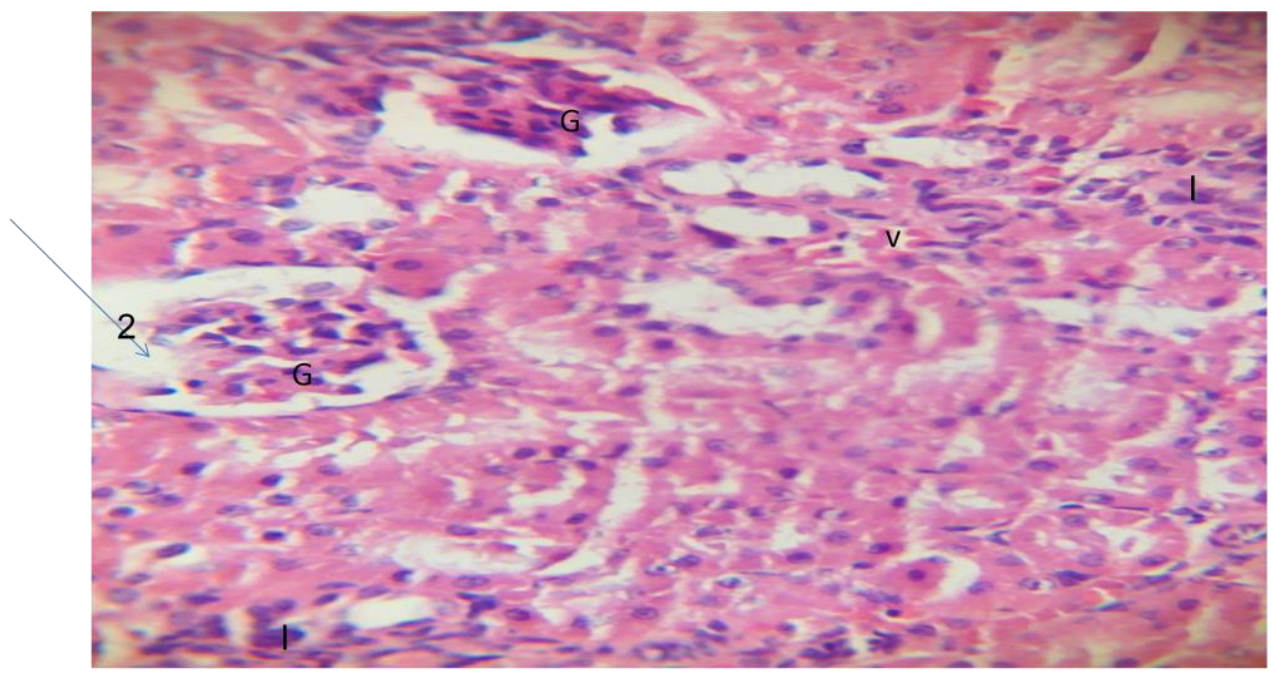

plate 3; photomicrograph $500 \mathrm{mg} \backslash \mathrm{kg}$,showing focal glomerular degeneration g, diffuse tubular degeneration, cortical lymphocytic infiltration (I), and edema fluid in (arrow2) HxE400 


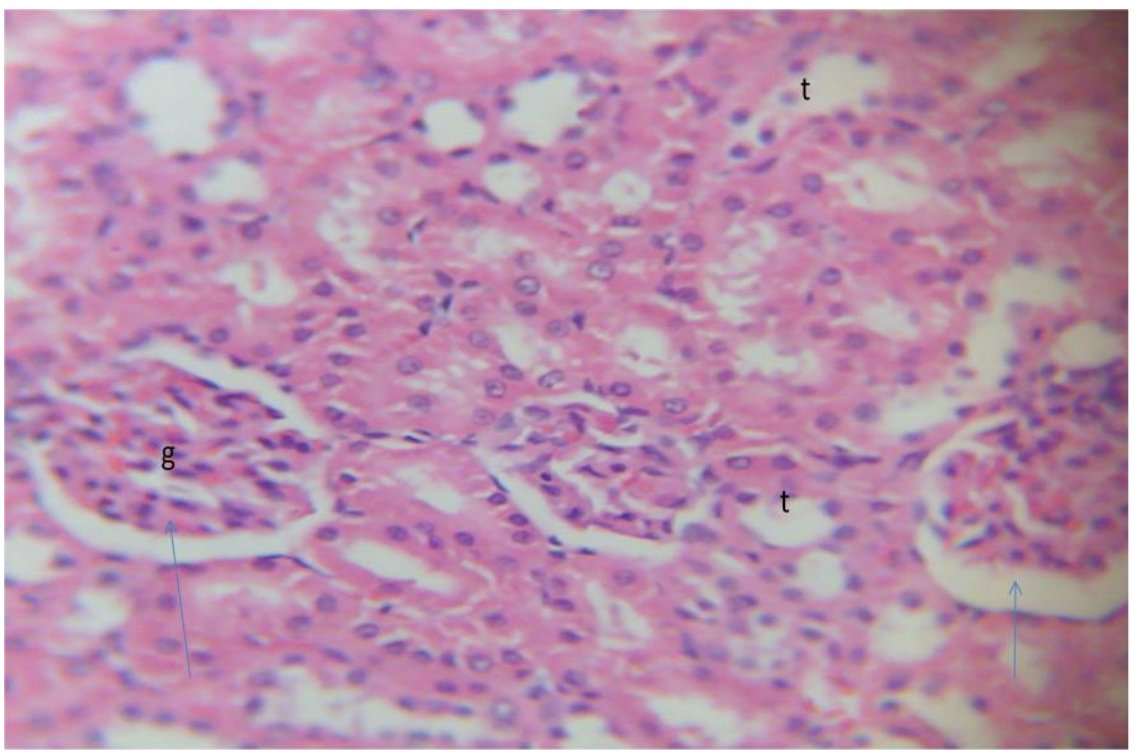

plate4, photomicrograph $400 \mathrm{mg} \backslash \mathrm{kg}$; showing fairly regenerating renal cortex; glomerulus g, encapsulated in moderately distended Bowman's space (arrow), renal tuble t. H\&EX400

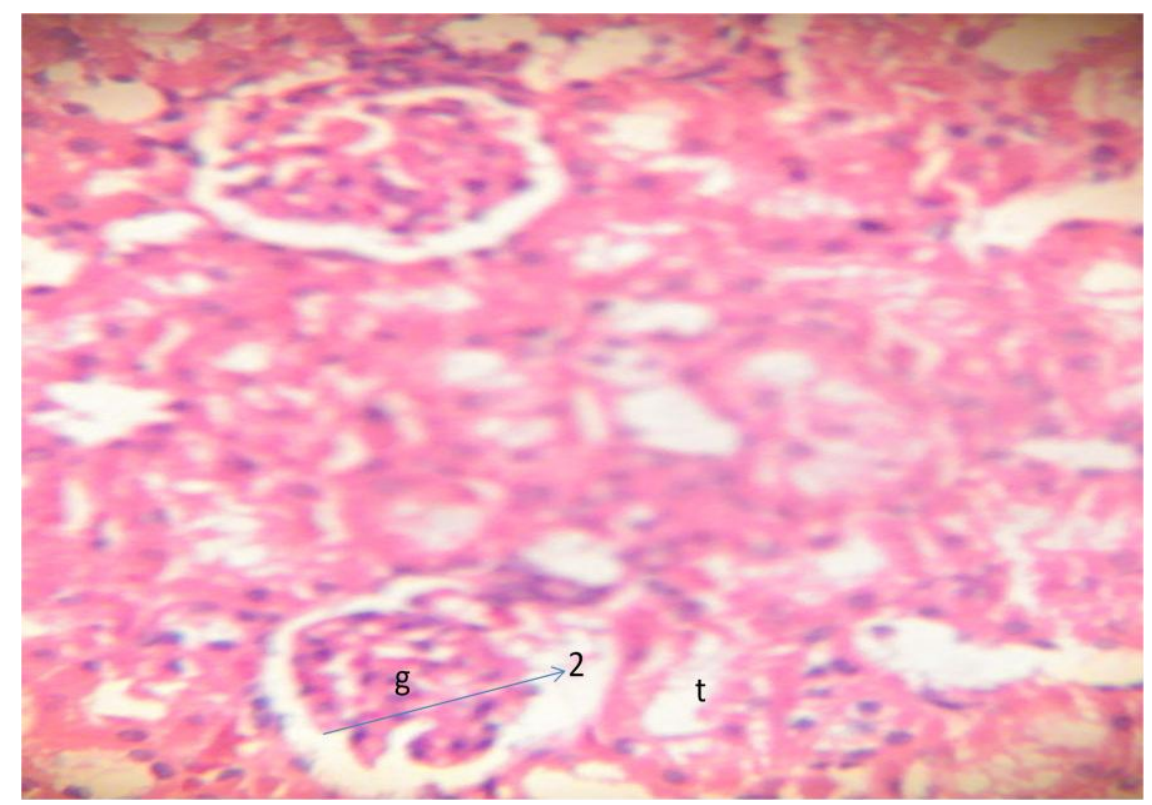

plate5, photomicrograph $300 \mathrm{mg} \backslash \mathrm{kg}$, showing moderate recovered renal cortex, moderate distension of bowman's space (arrow2), H\&Ex400

\section{Discussion:-}

The significant growth depression observed in rats administered with phenylhydrazine might be due to loss of appetite or malabsorption. Drugs that cause loss of appetite and gastrointestinal irritation in animals initiates poor absorption of essential nutrients leading to malnutrition and growth depression (Robbins et al., 1984).

Vernoniaamygdalina leaf extract appear to have protective role on phenylhydrazine induced and kidney toxicity in this study as it normalized the levels of ALT, AST urea, uric acid and creatinine in the serum and tissue close to that 
obtained in the control. These protective properties of the extract may be from the fact that the leaf is very rich in phytochemical ingredients with antioxidant properties (Singh et al., 1986). Bitter leaf has been reported to contain tannins, glycosides, cellulose, minerals like; potassium, calcium, phosphorus, iron, sulphur, manganese, sodium, and copper. Some of these chemical components enhances recovery of wound and tumor and also enhanced the healing of the renal structure and renal functioning (Ijeh, et al., 1996). The efficacy of any poison antidote depends on its capacity to either reduce the harmful effect or restoring the normal physiology caused by the poison. The observed restoration of normal functions to the damaged kidney by phenylhydrazine indicates its protective roles on the structural integrity of the organs.

The experimental animals treated with phenylhydrazine only were observed to produce body weakness, loss of appetite, decline body weight, respiratory distress. The loss of body weight may be due to depression in the central nervous system (cns) this could be caused by lesion in the hypothalamus of the brain. the above observation agrees with an earlier observations made by Appleton and Lang, (1987) who reported that exposure to phenylhydrazine depresses the central nervous system (cns), as a result reduces the body weight.

The photomicrograph, plate. 2 shows tubular degeneration, degeneration of the glomerulus, distention of the bowman's space, alteration of tubular epithelial cells, haemorrhage (h) and cortical lymphocytic infiltration, this agrees with the reports by Cohrsenet al,. (2001) and Dreishbachet al (1987); they reported that phenylhydrazine's exposure results in rupture of red blood as in the case of the hemorrhage observed; infiltration of the renal cortex by lymphocytes.

The photomicrograph, plate. 3 where $500 \mathrm{mg} / \mathrm{kg}$ aqueous extract of vernoniaamygdalina administered simultaneously with phenyl hydrazine in experimental group showed mild renal cortical damage and alteration of renal tubule. Late manifestation of gross and physical features observed, as were seen earlier in the experimental animal treated with phenyl hydrazine only. This suggested a possible protection of the extract against the onset of damage effect of phenyl hydrazine. These observations agree with the report by Clarke, (1978), Kasner and Tindall, (1984) who observed that in vivo application of bitter leaf extract have protection against renal inflammation, it also has anti-inflammatory and anti-toxic effect in the presence of toxic chemicals.

The result obtained in the experimental group four plates. 4 posts treated with $400 \mathrm{mg} / \mathrm{kg}$ of VernoniaAmygdalina for fourteen days showed recovery of the glomerulus, moderate distension of bowman's space, tubular epithelial cells and renal cortex recovery. These observations agree with the work done by Revbigie, (2005) who reported that the active constituent of the phyto-chemicals of bitter leaf are anti-tumoral and anti-urinary inflammatory, and enhances wound healing (Akpulu et al, 1994). The recovery and healing effect of vernoniaamygdalina was also observed in group five (5) post treated with $300 \mathrm{mg} / \mathrm{kg}$ for twenty eight (28) days shows moderate renal cortex. This also agrees with the report by Bosni et al (1995) that scientific administration of bitter leaf extract in a recommended dose is highly medicinal and act to heal wound, tumour recovery, and enhances body blood system. (Ologundeet al,. 1992) also observed that bitter leaf contains phytochemical factors that must be administered in a moderate dose to enhance the medicinal properties of bitter leaf.

Vernoniaamygdalina also contains active chemical composition like tannins, glycosides, cellulose, minerals like; potassium, calcium, phosphorus, iron, sulphur, manganese, sodium, and copper. Some of these chemical components enhances the recovery of wound and tumor and also enhanced the healing of the renal structure and renal functioning. These are evident in photomicrograph 4 and 5 as compared to photomicrograph 2 and 3 .

\section{Conclusion:-}

The results of the present investigation reveal that leaf extract of Vernoniaamygdalina (Bitter leaf) has protective effect on kidney damage in rat as it significantly reversed the observed disruption in cellular integrity caused by Phenylhydrazine. These findings corroborate the benefit of bitter leaf as a traditional remedy for the treatment of kidney diseases. 


\section{Acknowledgements:-}

Competing interests:-

Authors have declared that no competing interests exist.

\section{References:-}

1. Abasi, A. O., Raseroka B. H. (2003). In vivo anti - malarial activity of Vernonia amygdaline Br. J. Biomedical Sci 60(21:89 - 91).

2. Akah P. A. and Okafor C. I. (1992). Blood sugar lowering effect of vernoniaamygdalinadel, in an experimental rabbit model. Phytother. Res, 6:171 - 173.

3. Akinpelu, D. A. (1999). Anti - microbial activities of vernoniaamygdalina leaves. Fitoterapia. J. study med. Plants, 70; $432-435$.

4. Alabi, D. A. Onibudo, M. Z. and Amusa, N. A. (2005). World Journal of agricultural science 1, (1); $84-88$, 2005, ISSN $1817-3047$.

5. Anne, R. 1979, the role of wild foliage plants in the dict. A case study of lushota Tanzania. Ecol. Food Nutr. $8 ; 87-93$

6. Aregheore E. M. H. P. Makkar, S. K. Beeker(1998). Feed value of some browse plants from its central zone of Delta state, Nigeria. Trop sci. 38(2): $97-104$.

7. Aregheore, E. M. H. P, Makkar and S. K. Beeker (1997) chemical composition and tannin in leaves of some browse plant from delta (central nigeria) eaten by ruminants. Proc. Soc. Nutri. Physiol, 5: $11-15$

8. Guyton, A. C. and Hall, J. E. (2006). Textbook of Medical Physiology. 11th Ed. P 307.

9. Barbara, Y., James S. L. Alan S. and John W. H. (2006). Wheather's Functional Histology. 5th Ed. Page 307.

10. Bingham, E., Cohrssen, B. and Powel, C. H. (2001). Patty's Toxicology. Vol.1-9, 5th Ed. P. 1308.

11. Bonsi, M. L. K., Osuji, P. O., Tauh, A. K. and Umunua, N. N. (1995a). Vernoniaamygdalina as supplement to teff straw (Eragrostistel) fed to Ethiopian medic sheep. Agro - forestry system 31(3), pp229 - 241.

12. Brunt, P. W. Louswsky M. S. and Read A. E. (1984). The liver and the biliary system William Heinemann medical Books, ltd. London pp $19-23$.

13. Buttler, G. W. and Bailey R. W. (1973) Chemistry and Biology - chemistry of heritage, vol 1, and academic press London and New - York.

14. Clarke, E. G. C. and Clarke, M. L. (1978). Veterinary toxicology badleretindal, London pp $1-10$.

15. Clayton, G. D. and Clayton, F. E. (1981). Patty's Industrial Hygiene and Toxicology. 3rd Ed. New York. P 2805.

16. Hammonia, A. M. (1994). Pharmacological studies on vernoniaamygdalinadel, on Lithonia diverlitolic (gray). Vet. Med J. Giza 2: $91-97$.

17. Harris, P. F. and J. K. Kuglar (1971). Unusual monoclonal cells. Anatomy Journal 108:1.

18. Huffman M. A. (2003) animal self-medication - medication and ethno - medicine, exploration and exploitation of the medicinal properties of plant proceedings of the non - society 62(2) $1371-81$.

19. Hutchioson and Dalzell J. M. (1963). Flora of west Africa (2nd edition) agent London pp $450-455$.

20. Igile, G. O. W. Olasezk, S. Burda and M. Jurzysta (1995). Nutritional assessment of veroniaamygdalina leaves in growing mice. J. Agric. Food chem. 43: 2162 - 2166

21. Igile, G. W., Oleszek, M., Jurzysta, R., Aquino, N., Tomas and Pizza, C. (1995). vernoniosides D and E. two novel saponins from vernoniaamygdalina del. J. Natural prod. 58: 1438 - 1443.

22. Ijeh, I. Nwagbo V. O. Obidua O. (1996) comparative studies on nutritive phyto - chemical and anti - microbial properties of two varieties of vernoniaamygdalina plant pros. Res. Comm. 1: $71-75$.

23. Indebir Singh (2001), Human embryology, 7th edition pp. $187-188$.

24. Singh, I. (2002). A text book on histology with colour atlas, 4th edition pp $249-52(249-252)$.

25. Iwu, M. M. (1988). African ethno medicine celta, co. ltd. Enugu. Pp $40-50$.

26. Izevbigie, E. B., Bryant, J. L, Walker A. (2004) A novel natural inhibitor of extra cellular signal regulated kinases and human breast cancer cell growth. Experimental bio - med (Maywood) 229(2): 163 - 169.

27. Kashner A. and Tindall, R (1984), Ameri. J. of pharmacology 67:590 - 597.

28. Kupcham, S. M., Hernchway R. J., Karim. A. and Wermer D. (1996). Tumor inhibitors, XLVII, Vernodalin and vernomygdin. Two new, cytotoxic sesquelepene lactose from vernoniaamygdalina del, J. Org. chrin Dec 34(12): $3908-11$

29. Last R. J. (1984). Anatomy (regional and applied) 7th edition Pp $303-305$.

30. Moore, K. L. and Dally A. F. (2006). Clinically oriented anatomy 5th edition Lippincott's Williams amdwilkins publication, USA, ISBN 0-7817, 289 - 300 
31. Moore, K. L. and Persaud T. V. N. (2003). The development human clinical oriented embryology, 7th edition pp $264-265$

32. Ohigashi, M. (1994). Assessment of the anti - bacterial activity of some traditional medicine plants. Ethiopian. J. health dev. 13: $211-216$

33. Ologunde, M. O. Ayorinde, F. O. Sherphard R. K. Afolabi O. A. and O. L. (1992). Sterol of seed oil of vernoniagalanesismaranthuscrunthus growth in the humid tropics. J. of food Agric. 58. Pp $221-225$.

34. Pathol, A. M. J. (2001). Role of trophic tubules in development of interstitial fibrosis in microembolism pp7585 .

35. Romanes G. J. (1997). Cunningham manual of practical anatomy, 15th edition, vol 2 Oxford University press inc. New - York.

36. Sadler, T. W. (2000). Langman's Medical Embryology. 8th Ed, P. 304-312.

37. Shepherd, T. H. (1986). Catalog of Teratogenic Agents. 5th Ed. The John's Hopkins University Press. P.454.

38. Sofowora, A. (1993). Medicinal Plants and Traditional Medicine in Africa. 2nd Ed. Spectrum Book Ltd. Ibadan.

39. Uhegbu, F. O. and Ogbuchi, K. J. (2004) effect of the aqueous extract (crude) of leaves of vernoniaamygdalina on blood glucose, serum cholesterol and serum albumin level in alloxan induced diabetic albino rat. Global. J, pure applied sci. 10: 189 - 194.

40. WHO (1991) Guide name for assessment of herbal medicine programmed and traditional medicine WHO/TRIM 914 Geneva.

41. William, B. and Don, W. F. (1995). A text book of histology 10th edition pp $688-705$.

42. Williams P. L., Barnistar L. H., Berry M. M., Collin P., D. M., Dussek, J. E., Ferguson M. W. (1995): Gray'sAnatomy, the anatomical basis of medicine and surgery. 38th British edition. New - York, Churchill, Livingstone pp 932. 